\title{
Extrém magas B típusú natriureticus prohormon prognosztikai szerepe a szívelégtelenség miatt kezelt betegek kórházi halálozására
}

\author{
Bózsik Béla dr. - Nagy Erzsébet dr. \\ Somlói Miklós dr. - Tomcsányi János dr. \\ Betegápoló Irgalmasrend Budai Irgalmasrendi Kórháza, Kardiológia, Budapest
}

\begin{abstract}
Bevezetés: A szívelégtelenség miatt hospitalizált szívelégtelen betegek kórházi és egyéves halálozása igen magas. A natriureticus peptideknek a szívelégtelenség diagnosztikája mellett a prognosztikában is jelentőss szerepe van. A natriureticus peptideknek a kórházi kezelésre történő változása ismert prognosztikai tényezőo. Keveset tudunk a kórházi felvételkor mért extrém magas natriureticus peptideknek a prognosztikai értékéról a kórházi halálozásra vonatkozóan. Célkitüzés: Annak eldöntése, hogy az extrém magas B típusú natriureticus peptidnek van-e prognosztikai jelentősége a kórházi halálozásra.

Módszer: Retrospektív adatgyújtés a 2006-2016 között a Budai Irgalmasrendi Kórház Kardiológia Osztályán kezelt szívelégtelen betegek felvételi NT-proBNP szintjének és kórházi halálozásának a szempontjából. Külön vizsgáltuk a 2015-ben szívelégtelenség miatt hospitalizált olyan szívelégteleneket, akiknek a felvételi NT-proBNP szintjét extrém magasnak tartottuk. Itt a határt $10000 \mathrm{ng} / \mathrm{l}$ feletti értéknél szabtuk meg. E betegeknél a szívelégtelenség komorbiditásait is figyelembe vettük.

Eredmények: Az elmúlt 10 évben 3143, kórházat elhagyó beteg medián NT-proBNP értéke 4842 ng/1 volt, míg a 182, kórházban meghalt beteg medián NT-proBNP értéke 10688 ng/l-nek adódott $(\mathrm{p}<0,001)$. 2015-ben 118 olyan szívelégtelen beteget kezeltünk, akiknek az NT-proBNP értéke 10000 ng/l felett volt. A kórházban meghaltak száma 13 volt, ami több mint 10\%-os halálozást jelentett, szemben az összes szívelégtelen beteg 5,8\%-os halálozásával. Az extrém magas NT-proBNP-vel felvett betegeknél már nem volt szignifikáns különbség az elhunyt, illetve túlélő betegek medián értékei között (17 $080 \mathrm{ng} / \mathrm{l}$ versus $19152 \mathrm{ng} / \mathrm{l})$.

Következtetés: A felvételi NT-proBNP esetén a 10000 ng/l feletti érték szignifikáns kórházi mortalitásnövekedést jelent. A $10000 \mathrm{ng} / \mathrm{l}$ feletti tartományban már nincsen szignifikáns különbség a túlélők és meghaltak értékei között. Nincsen olyan etiológiai tényező, amit egyértelmúen felelőssé lehetne tenni az extrém magas NT-proBNP értékekért, illetve a halálozásért.
\end{abstract}

Orv Hetil. 2017; 158(20): 779-782.

Kulcsszavak: szívelégtelenség, kórházi halálozás, natriureticus peptid

The prognostic role of extremely high levels of the B-type natriuretic prohormone with regard to the in-hospital mortality of patients hospitalized for heart failure

\footnotetext{
Introduction: Patients hospitalized for heart failure have a very high in-hospital as well as one-year mortality. Natriuretic peptides play both a diagnostic and a prognostic role in this disease. Changes of natriuretic peptide levels in response to therapy are a well-known prognostic marker. Regarding in-hospital mortality, however, little is known about the prognostic value of extremely high levels of natriuretic peptides measured on admission.

Aim: To decide whether extremely high levels of B-type natriuretic peptide have a prognostic value with regard to inhospital mortality.

Method: NT-proBNP levels on admission and in-hospital mortality were extracted retrospectively from the data of patients treated with heart failure in the cardiology department of the Hospital of St. John of God in Budapest. We separately analyzed the data of patients hospitalized for heart failure in 2015 with extremely high initial NT-proBNP levels. The cut-off value in this regard was $10000 \mathrm{ng} / \mathrm{l}$. We also analyzed the comorbidities of these patients.
} 
Results: The median NT-proBNP level of those patients who survived beyond the index hospital stay in the last 10 years was $4842 \mathrm{ng} / \mathrm{l}$, whereas the median NT-proBNP level of those 182 patients who died during their hospital stay was $10688 \mathrm{ng} / \mathrm{l}(\mathrm{p}<0.001)$. In the year 2015, we treated 118 patients with an NT-proBNP level above $10000 \mathrm{ng} / \mathrm{l}$. Thirteen of these patients died, which means that their in-hospital mortality exceeded $10 \%$. In comparison, the inhospital mortality of all heart failure patients was $5.8 \%$. The difference of median NT-proBNP levels of surviving versus deceased patients in this group with extremely high NT-proBNP levels was no longer significant (17 $080 \mathrm{ng} / \mathrm{l}$ vs. $19152 \mathrm{ng} / \mathrm{l})$.

Conclusions: Patients with an NT-proBNP level of $>10000 \mathrm{ng} / \mathrm{l}$ on admission have a significantly higher in-hospital mortality. The difference of NT-proBNP levels of surviving versus deceased patients in the group with admission NT-proBNP levels $>10000 \mathrm{ng} / \mathrm{l}$ is no longer significant. We could not identify any etiological factors that would explain these extremely high NT-proBNP levels or the excess in-hospital mortality.

Keywords: heart failure, in-hospital mortality, natriuretic peptide

Bózsik B, Nagy E, Somlói M, Tomcsányi J. [The prognostic role of extremely high levels of the B-type natriuretic prohormone with regard to the in-hospital mortality of patients hospitalized for heart failure]. Orv Hetil. 2017; 158(20): 779-782.

(Beérkezett: 2017. március 19.; elfogadva: 2017. április 12.)

A szívelégtelenség egy gyakori és komplex cardiovascularis betegség, ami gyakori oka a kórházi hospitalizációnak $[1,2]$. A kezelés szempontjából a legfontosabb szerepe a neurohumoralis aktivitás blokkolásának van. A klinikai gyakorlatban a legerősebb prognosztikai biomarker a natriureticus peptid, ami egy jól ismert indikátora a neurohumoralis aktivitásnak $[3,4]$. A B típusú natriureticus prohormon (NT-proBNP) prognosztikai szerepét elsősorban a kezelés hatására bekövetkező változásban látják a rehospitalizáció és a korai, illetve késôi mortalitás szempontjából [5]. Az NT-proBNP prognosztikai értéke nem különbözik a megtartott és a csökkent balkamrafunkciójú betegeknél [6]. Hazai adatok azt mutatták, hogy az új keletú, illetve adott évben hospitalizált szívelégtelen betegek éves mortalitása $27 \%$, illetve $25 \%$, szemben az adott évben nem hospitalizált szívelégtelen betegek 10\%-os éves mortalitásával [7].

A szívelégtelenség miatt hospitalizált betegek felvételi NT-proBNP értékeinek a kórházi halálozásra gyakorolt prognosztikai értéke sem nemzetközi, sem hazai adatokból nem ismert. Ezért ezt a kérdést vizsgáltuk osztályunk beteganyagának retrospektív áttekintésével.

\section{Betegek és módszer}

A vizsgálat retrospektív adatgyúijtésen alapult. Szívelégtelen betegnek tekintettük, aki a Framingham-kritériumnak megfelelt [8] és a kórházból való távozáskor is ezzel a diagnózissal lett elbocsátva. NT-proBNP mérés rutinszerúen 2006 óta zajlik osztályunkon a szívelégtelenség miatt felvett betegeknél. Egyrészt megvizsgáltuk a 2006-2016 közötti összes, szívelégtelenség miatt hospitalizált beteg felvételi NT-proBNP adatát a kórházi halálozás szempontjából. Másrészt azoknak a 2015-ben szívelégtelenséggel kezelt betegeknek a klinikai adatait gyújtöttük össze, akiknél a felvételi NT-proBNP érték a mortalitás szempontjából is releváns extrém magas, $10000 \mathrm{ng} / \mathrm{l}$ felett volt. Az NT-proBNP mérésre az Elecsys immunkémiai módszert használtuk (Roche). $35000 \mathrm{ng} / \mathrm{l}$ felett hígításos módszerrel lett meghatározva a pontos NT-proBNP érték. Nem kerültek beválogatásra azok a betegek, akiknél az akut szívelégtelenséget akut coronariaszindróma okozta. Akut coronariaszindróma alatt klinikai diagnózist értettünk, tehát a troponin-T-pozitivitás még nem jelentette önmagában a kizárást.

\section{Statisztika}

A kategorikus változók eloszlásának vizsgálatára Fischerféle egzakt tesztet, a numerikus változókra kétmintás Tpróbát, az NT-proBNP összehasonlítására a MannWhitney-féle U-tesztet alkalmaztuk.

\section{Eredmények}

A 2006-2016 között kezelt szívelégtelen betegeknél azt találtuk, hogy a 3143, kórházat elhagyó beteg medián NT-proBNP értéke 4842 ng/l volt, míg a 182, kórházban meghalt beteg medián NT-proBNP értéke $10688 \mathrm{ng} / \mathrm{l}$-nek adódott. Amint az l. ábra mutatja, a két csoport közti különbség szignifikáns volt $(\mathrm{p}<0,001)$.

Ha a halálozás kvartilisekre osztott megoszlását nézzük, akkor a negyedik kvartilisben látható szignifikáns mortalitás, ott, ahol az NT-proBNP 10720 ng/l volt (2. ábra).

A retrospektív vizsgálat második részében, a 2015-ös évben 118 olyan szívelégtelen beteget kezeltünk, akinek az NT-proBNP értéke 10000 ng/l felett volt. A kórházban meghaltak száma 13 volt, ami több mint $10 \%$-os halálozást jelentett, szemben az összes szívelégtelen beteg 5,8\%-os halálozásával. Az NT-proBNP értékek között 


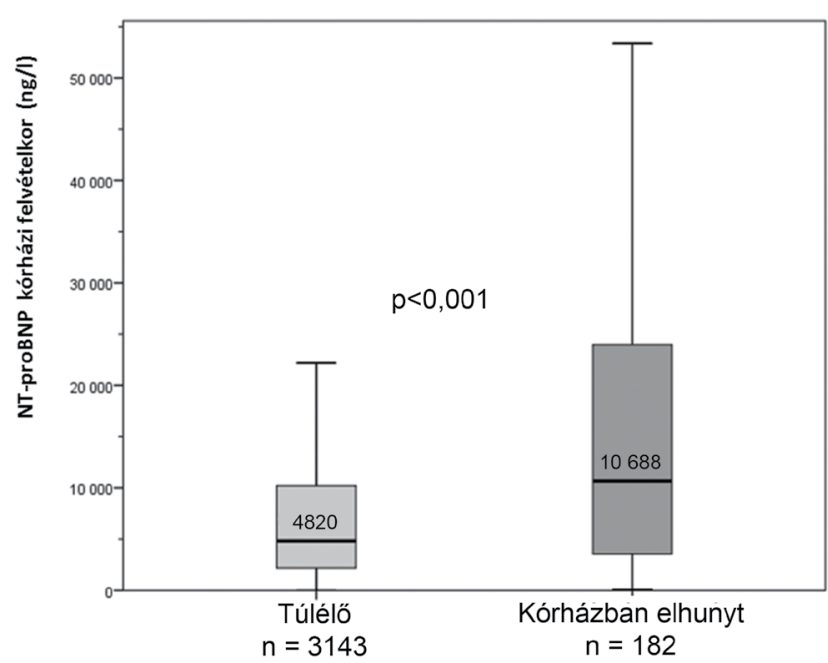

l. ábra $\quad$ A 2006-2016 közötti szívelégtelen betegek NT-proBNP értékei a kórházi halálozás szerint kettébontva

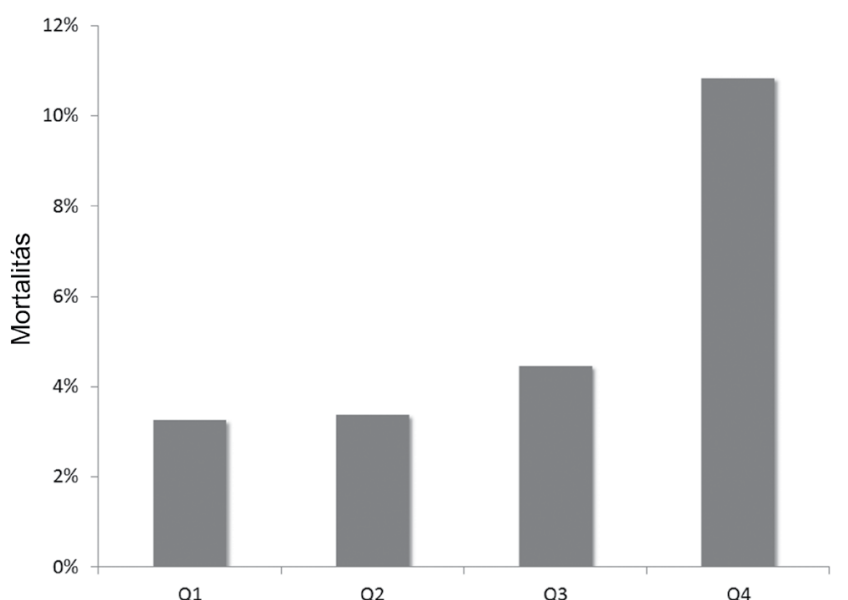

2. ábra

A mortalitás kvartilisek szerinti megoszlása 3325 betegnél. A negyedik kvartilisnél a különbség szignifikáns $(\mathrm{p}<0,001)$, NT-proBNP $10720 \mathrm{ng} / \mathrm{l}$

már nem volt szignifikáns különbség a medián értékek tekintetében ebben az extrém magas NT-proBNP-vel felvett csoportban (17 $080 \mathrm{ng} / 1$ versus $19152 \mathrm{ng} / \mathrm{l}$ ), amint ezt a 3. ábra demonstrálja.

A 2015-ben szívelégtelenséggel kezeltek komorbiditásait vizsgálva azt találtuk, hogy a túlélők és meghaltak között szignifikáns különbség csak a troponin-T- és a hemoglobinértékekben volt, valamint akkor, ha az anamnézisben anaemia, veseelégtelenség és ischaemiás etiológia szerepelt (1. táblázat).

\section{Megbeszélés}

A felvételi NT-proBNP kórházi halálozás prognózisára vonatkozó - nagy betegszámon alapuló - adatokat nem találunk, ezért a retrospektív adatgyüjtést hiánypótlónak gondoljuk.

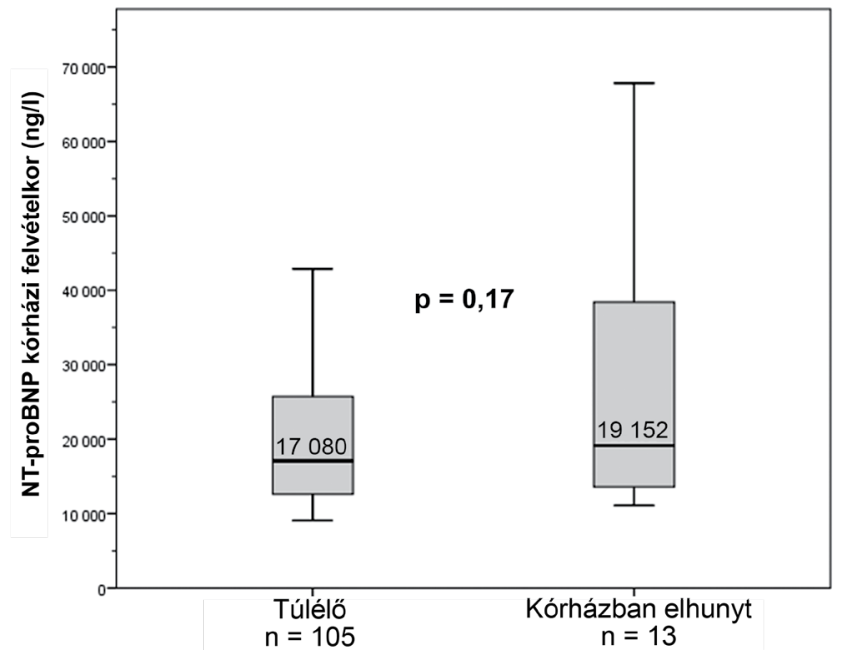

3. ábra $\mid$ Extrém magas NT-proBNP és kórházi halálozás a 2015-ben szívelégtelenség miatt felvett betegeknél $(\mathrm{n}=118)$

A vizsgálat főbb eredményei a következők voltak:

1. A felvételi NT-proBNP esetén a $10000 \mathrm{ng} / 1$ feletti érték szignifikáns kórházi mortalitásnövekedést jelent.

2. A $10000 \mathrm{ng} / 1$ feletti tartományban már nincsen szignifikáns különbség a túlélők és meghaltak értékei között.

3. Nincsen olyan etiológiai tényező, amit egyértelmúen felelőssé lehetne tenni az extrém magas NT-proBNP értékekért, illetve a halálozásért. A troponint nem önálló etiológiai tényezőnek, hanem a szívizom-károsodás markerének tekintettük.

A vizsgálat fontosabb korlátai a következők:

1. Nem vizsgáltuk a hospitalizációt jelentő szívelégtelenség akut okát, mert az esetek egy részében ez nem volt kideríthető, illetve multifaktoriálisnak gondoltuk.

1. táblázat $\mid$ Komorbiditások és epidemiológiai tényezók összehasonlítása a 2015-ben szívelégtelenséggel kezelt betegeknél

\begin{tabular}{lccc}
\hline Változó & $\begin{array}{c}\text { Kórházban } \\
\text { meghaltak }\end{array}$ & Túlélók & $\mathrm{p}$ \\
\hline Férfi & $67 \%$ & $56 \%$ & 0,553 \\
Életkor & 78,6 & 76,0 & 0,561 \\
Hgb & 111 & 127 & 0,024 \\
Creatinin & 250 & 162 & 0,087 \\
GFR & 31 & 46 & 0,172 \\
Troponin, ng/1 & 650 & 167 & $<0,001$ \\
Afi & $62 \%$ & $40 \%$ & 0,151 \\
HPT & $58 \%$ & $49 \%$ & 0,762 \\
Anaemia & $67 \%$ & $22 \%$ & 0,002 \\
COPD & $25 \%$ & $0,1 \%$ & 0,379 \\
Veseelégtelenség & $92 \%$ & $49 \%$ & 0,005 \\
DM & $25 \%$ & $33 \%$ & 0,749 \\
ISZB & $85 \%$ & $44 \%$ & 0,007 \\
ValvHF & $23 \%$ & $13 \%$ & 0,386 \\
\hline
\end{tabular}


2. Ugyanezért nem vizsgáltuk a kórházi halálozás közvetlen okát sem.

3. Az NT-proBNP esetében csak egy felvételi NT-proBNP értéket néztünk és nem vizsgáltuk annak a kinetikáját az elkövetkező 6-12 órában (mivel ismételt mérések csak néhány betegnél álltak rendelkezésre), ami további emelkedést jelenthetett volna az esetek egy részében.

\section{Következtetés}

Elmondható, hogy a felvételi NT-proBNP értéknek nemcsak diagnosztikus, hanem rövid távú prognosztikai értéke is van, amennyiben extrém magas. Ez az érték kerekítve $10000 \mathrm{ng} / \mathrm{l}$ feletti NT-proBNP-t jelent.

E megfigyelésünk nagyobb betegszámon alátámasztja Omar és mtsai vizsgálatát, akik nemrég publikálták, hogy az extrém felvételi BNP nem reprezentálja sem a congestio mértékét, sem a rehospitalizációt, de a hat hónapos összmortalitást igen [9]. Hozzátehetjük, hogy NTproBNP esetében ez már igaz a kórházi halálozásra is. Végezetül ismételten hangsúlyozni kell, hogy megállapításaink megerősítésére egy hasonlóan nagy betegszámú prospektív vizsgálat szükséges.

Anyagi támogatás: A közlemény megírásával kapcsolatban a szerzők anyagi támogatásban nem részesültek.

Szerzői munkamegosztás: B. B.: A közlemény megírása. N. E.: Laboradatok gyújtése. S. M.: Statisztikai feladatok végzése. T. J.: Szakmai javaslatok a cikk írásához. A cikk végleges változatát valamennyi szerző elolvasta és jóváhagyta.
Érdekeltség: A szerzőknek nincsenek a cikk megírásával, illetve tartalmával kapcsolatban érdekeltségei.

\section{Irodalom}

[1] McMurray, J. J., Stewart, S.: The burden of heart failure. Eur. Heart J. Suppl., 2002, 4(Suppl. D), D50-D58.

[2] Owan, T. E., Hodge, D. O., Herges, R. M., et al.: Trends in prevalence and outcome of heart failure with preserved ejection fraction. N. Engl. J. Med ., 2006, 355, 251-259.

[3] Braunwald, E.: Biomarkers in heart failure. N. Engl. J. Med., 2008, 358, 2148-2159.

[4] Kovács, L. G., Nyolczas, N., Habon, T., et al.: Measurement of natriuretic peptides in heart failure: the good laboratory and clinical practice. [Natriureticus peptidek mérése szívelégtelen betegeken: a helyes laboratóriumi és klinikai gyakorlat.] Orv. Hetil., 2015, 156, 1235-1245. [Hungarian]

[5] Baggish, A. L., van Kimmenade, R. R., Januzzi, J. L. Jr:: Aminoterminal pro-B-type natriuretic peptide testing and prognosis in patients with acute dyspnea, including those with acute heart failure. Am. J. Cardiol., 2008, 101(3 Suppl.), S49-S55.

[6] Kang, S. H., Park, J. J., Choi, D. J., et al.: Prognostic value NTproBNP in heart failure with preserved versus reduced EF. Heart, 2015, 101, 1881-1888.

[7] Tomcsányi, J., Toth, E.: Epidemiology and therapy of heart failure in the early XXI century. [Szívelégtelenség epidemiológiája és terápiája Magyarországon a XXI. század elején.] Card. Hung., $2012,42,42-49$.

[8] McKee, P. A., Castelli, W. P., McNamara, P. H., et al.: The natural history of congestive heart failure: the Framingham study. N. Engl. J. Med., 1971, 285, 1441-1446.

[9] Omar, H. R., Guglin, M.: Extremely elevated BNP in acute heart failure: Patient characteristics and outcomes. Int. J. Cardiol., 2016, 218, 120-125.

(Tomcsányi János dr., Budapest, Árpád fejedelem u. 7., 1023 e-mail: tomcsanyij@gmail.com)

\section{Tisztelt Szerzőink, Olvasóink!}

Az Orvosi Hetilapban megjelenő/megjelent közlemények elérhetőségére több lehetőség kínálkozik.

Rendelhető különlenyomat, melynek áráról bővebben a www.akkrt.hu honlapon (Folyóirat Szerzőknek, Különlenyomat menüpont alatt) vagy Szerkesztöségünkben tájékozódhatnak.

A közlemények megvásárolhatók pdf-formátumban is, illetve igényelhető Optional Open Article (www.oopenart.com).

Adott dij ellenében az online közlemények bárki számára hozzáférhetök honlapunkon (a közlemények külön linket kapnak, így más oldalról is linkelhetővé válnak).

Bővebb információ a hirdetes@akkrt.hu címen vagy különlenyomat rendelése esetén a Szerkesztőségtöl kérhető. 